\title{
One very rare and one new tracheal tumour found by electron microscopy: glomus tumour and acinic cell tumour resembling carcinoid tumours by light microscopy
}

\author{
BRIAN E HEARD, ANN DEWAR, RICHARD K FIRMIN, STUART C LENNOX \\ From the Cardiothoracic Institute and Brompton Hospital, London
}

ABSTRACT Tracheal tumours were removed surgically from two patients and diagnosed as carcinoid tumours by routine light microscopy. At a later date, electron microscopy was performed on stored tumour tissue and no neurosecretory granules were found in either case. One showed features of a glomus tumour and the other of an acinic cell tumour. Only two glomus tumours appear to have been reported previously in the trachea, and no acinic cell tumours. Electron microscopy is thus sometimes of great assistance in diagnosing accurately unusual tumours of the lower respiratory tract.

We have seen two patients in the last five years with tracheal neoplasms that were diagnosed by routine pathological methods as carcinoid tumours. To confirm the diagnosis before publication, we examined each tumour under the electron microscope. To our surprise, the electron micrographs clearly demonstrated that neither could be a carcinoid tumour. One was a glomus tumour and the other an acinic cell tumour. Reports of only two glomus tumours of the trachea were found, 12 and the acinic cell tumour appears to be the first on record in the trachea.

\section{Case 1}

\section{CLINICAL HISTORY}

A 50-year-old man presented, as tracheal tumours often do, with "late onset asthma". After receiving unsuccessful treatment with steroids and bronchodilators, he was referred almost moribund for resection of a tracheal tumour. The tumour could be seen in the plain chest radiographs but was clearer in the tomograms, lying in the lower one-third of the trachea (fig 1). It was excised together with a cylinder of trachea through a right thoracotomy incision, and the trachea was reconstructed by end-to-end anastomosis.

Address for reprint requests: Professor BE Heard, Cardiothoracic Institute and Brompton Hospital, London SW3 6HP.
After operation he developed sputum retention and pneumonia and required mechanical ventilation and repeated bronchoscopy. An empyema developed which was drained, and he became endotoxaemic and anuric. All supportive measures proved inadequate and he died on the fifteenth postoperative day. A necropsy was not performed.

\section{PATHOLOGY}

The surgical specimen consisted of a cylinder of trachea $2.5 \mathrm{~cm}$ long, containing a smooth round polypoid neoplasm $2.5 \times 1.5 \times 1.0 \mathrm{~cm}$, occupying most of the lumen and arising from the posterior wall.

Routine paraffin sections stained with haematoxylin and eosin revealed irregular masses of mediumsized uniform polyhedral cells with central, delicately stained round nuclei, surrounded by a small amount of moderately eosinophilic cytoplasm (fig 2). Mitoses were rare. Many vascular channels traversed the tumour, and tumour cells were present in the tracheal muscle coat, and through to the edge of the specimen. It was originally diagnosed as a carcinoid tumour. The respiratory epithelium over the growth showed squamous metaplasia. At a later date, small pieces were taken from the tumour which had been stored in aqueous formalin and were post-fixed in glutaraldehyde and osmic acid, and embedded in Araldite. Sections $1 \mu \mathrm{m}$ thick were cut and then stained by toluidine blue for initial light microscopy. The tumour cells were seen more distinctly in this 


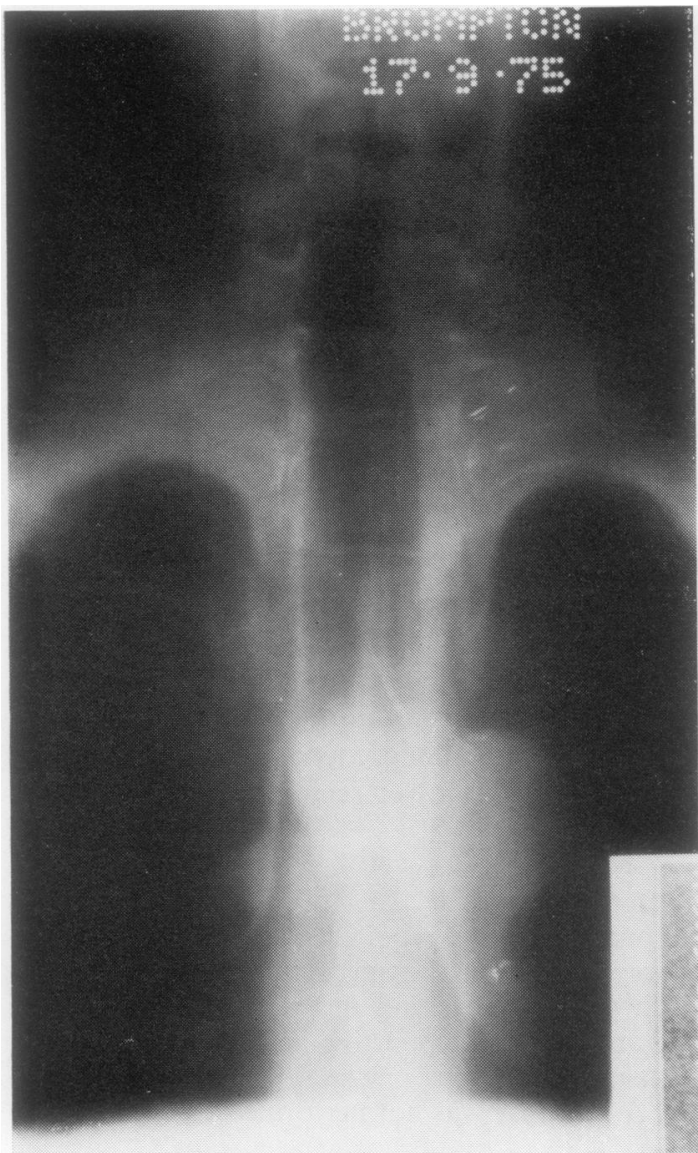

Fig 1 Case 1: tomogram showing a tumour lying in the lumen of the lower one-third of the trachea. way, some being polygonal and others spindleshaped.

Ultrathin sections $(80 \mathrm{~nm}$ ) were cut from the same Araldite blocks and examined by electron microscopy. The original diagnosis of carcinoid tumour was ruled out by the absence of neurosecretory granules from the tumour cells. Instead, many of them showed intracytoplasmic microfilaments with dense bodies; along the plasma membranes were rows of small regular pinocytotic vesicles and also some small flat dense plaques parallel to the membrane (fig 3). A limited amount of basement membrane substance was present between the tumour cells in places. These various features occur together only with smooth muscle cells and glomus cells, and in their corresponding tumours. The regular polygonal shape of many of the tumour cells, and the way they were arranged around the prominent blood vessels (seen best in $1 \mu \mathrm{m}$-thick sections), indicated glomus tumour rather than leiomyoma.

After electron microscopy, paraffin sections were reviewed for light microscopy evidence of glomus tumour, using special stains. Reticulin staining (Glees' Method) revealed many fine reticulin fibres lying between individual tumour cells, as well as more densely around collections of cells (fig 4). No intracytoplasmic granules of the carcinoid type were stainable by Grimelius' method. ${ }^{3}$

\section{Case 2}

CLINICAL HISTORY

A 54-year-old man presented to his local hospital with a three-year history of haemoptysis. A tumour was apparent on the chest radiograph, but was more

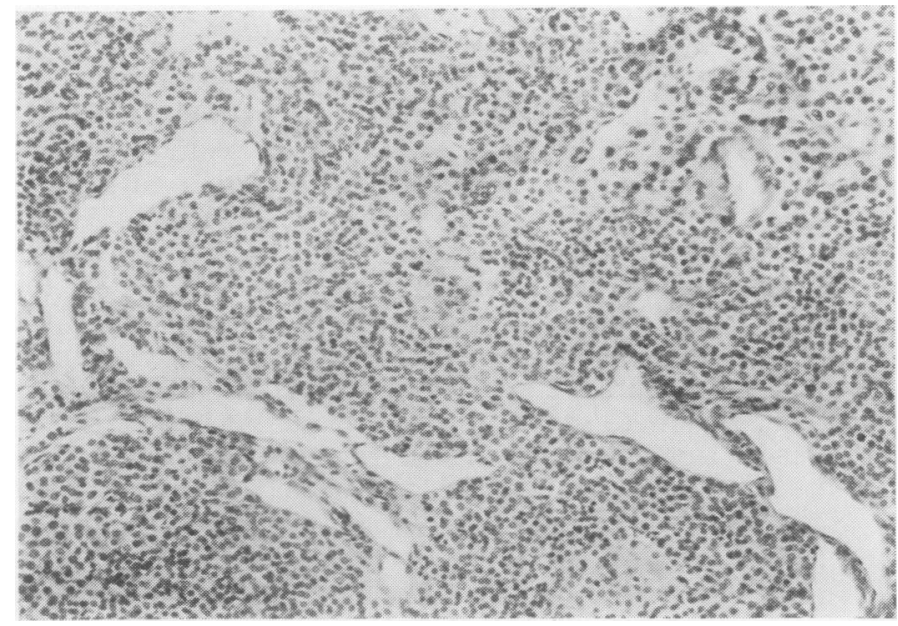

Fig 2 Case 1: glomus tumour of trachea showing sheets of small uniform cells and thin-walled blood vessels. $H$ and $E$, magnification $\times 40$. 




Fig 3 Case 1: glomus tumour of trachea showing intracytoplasmic fibrils $(F)$, dense bodies $(D B)$, pinocytotic vesicles $(V)$, and dense plaques (DP). Basement membrane substance is present between cells $(B M)$. Electron micrograph, original magnification $\times 12200$.

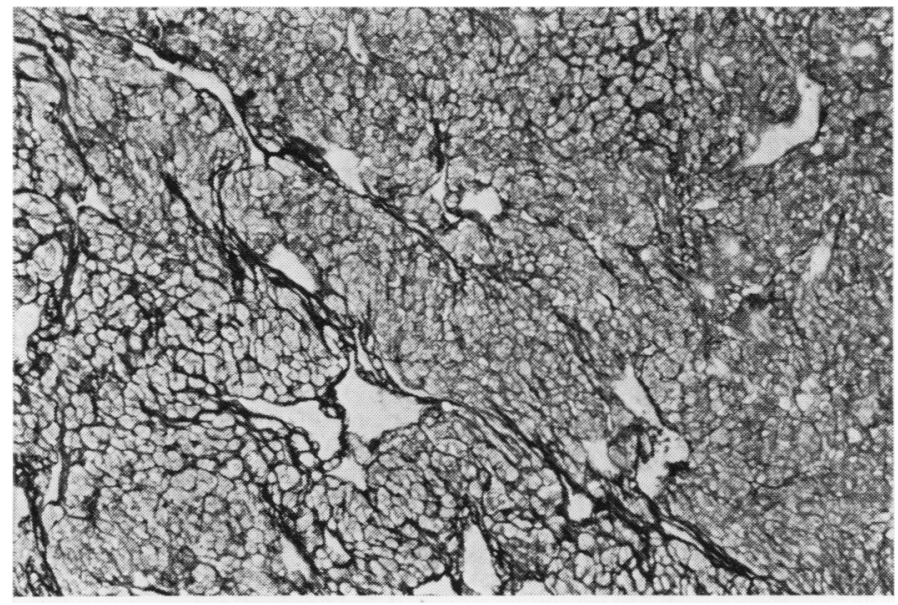

Fig 4 Case 1: glomus tumour of trachea showing fine reticulin fibres lying between individual tumour cells. Glees' stain, magnification $\times 40$.

clearly identified by tomography, lying in the middle one-third of the trachea. The tumour was biopsied at bronchoscopy by the referring surgeon ( $\mathrm{Mr} \mathrm{R}$ Jeffrey, Basildon Hospital). This biopsy suggested that the tumour was a carcinoid. The tumour was explored through a cervical incision and excised with a cylinder of trachea. The trachea was reconstructed by end-to-end anastomosis. He made an uneventful recovery and has remained well in the two years since his operation.

\section{PATHOLOGY}

The specimen consisted of a short cylinder of trachea about $1.5 \mathrm{~cm}$ long, containing a smooth round polypoid tumour $2.2 \mathrm{~cm}$ long arising from the posterior wall and projecting out from one end of the cylinder.

Routine paraffin sections stained with haematoxylin and eosin showed sharp-edged masses of spindledshaped or columnar tumour cells with central regular, round or oval pale-staining nuclei (fig 5). In 




Fig 5 Case 2: acinic cell tumour of trachea showing an area of tightlypacked, roughly spindle-shaped tumour cells with small regular nuclei. A few globules of secretion are present. $H$ and $E$, magnification $\times 95$.

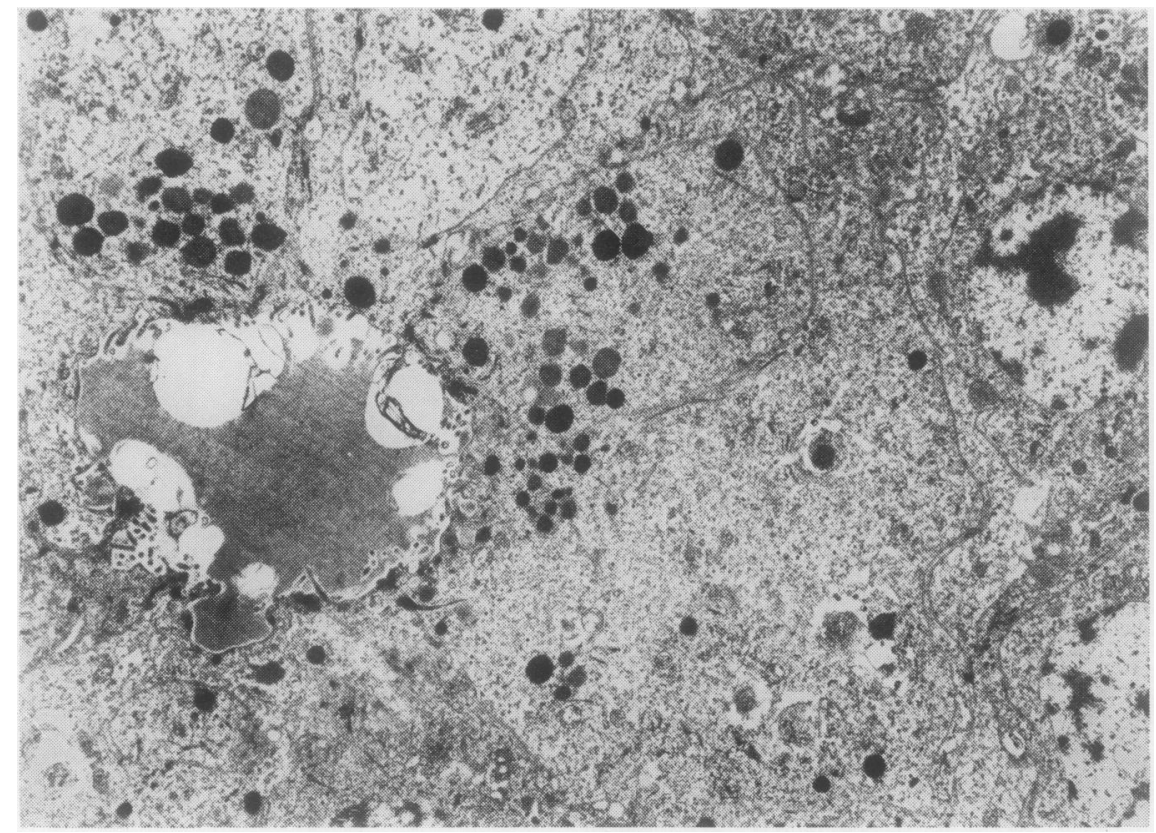

Fig 6 Case 2: acinic cell tumour of trachea. Dense granules are seen in the tumour cells around the lumen on the left. Electron micrograph, original magnification $\times 7000$.

some areas the cells were arranged more loosely in a trabecular pattern. The cytoplasm was pale or moderately eosinophilic, with indistinct, slightly basophilic granules. Mitoses were not numerous (approximately 1 per 10 high power fields). Foci of necrosis of the tumour with calcification were present. Among the tumour cells in some areas were small globules of brightly-eosinophilic proteinous material. Proper tubule formation around the globules was not a feature. The respiratory epithelium over the growth showed squamous metaplasia. Tumour cell masses were present through to the outside of the tracheal wall.

Tumour tissue stored in formalin was processed further as for case 1 . Sections $1 \mu \mathrm{m}$ thick stained by toluidine blue showed dark granules in some tumour cells. Electron microscopy revealed more information on the granules. They were round, dense, and membrane-bound and measured 225 to $950 \mathrm{~nm}$ in diameter (mean value $440 \mathrm{~nm}$ ), which is larger than the neurosecretory granules of carcinoid tumours. They tended to cluster at one pole of the cell, particularly towards occasional primitive lumina containing accumulations of grey-staining, finely 


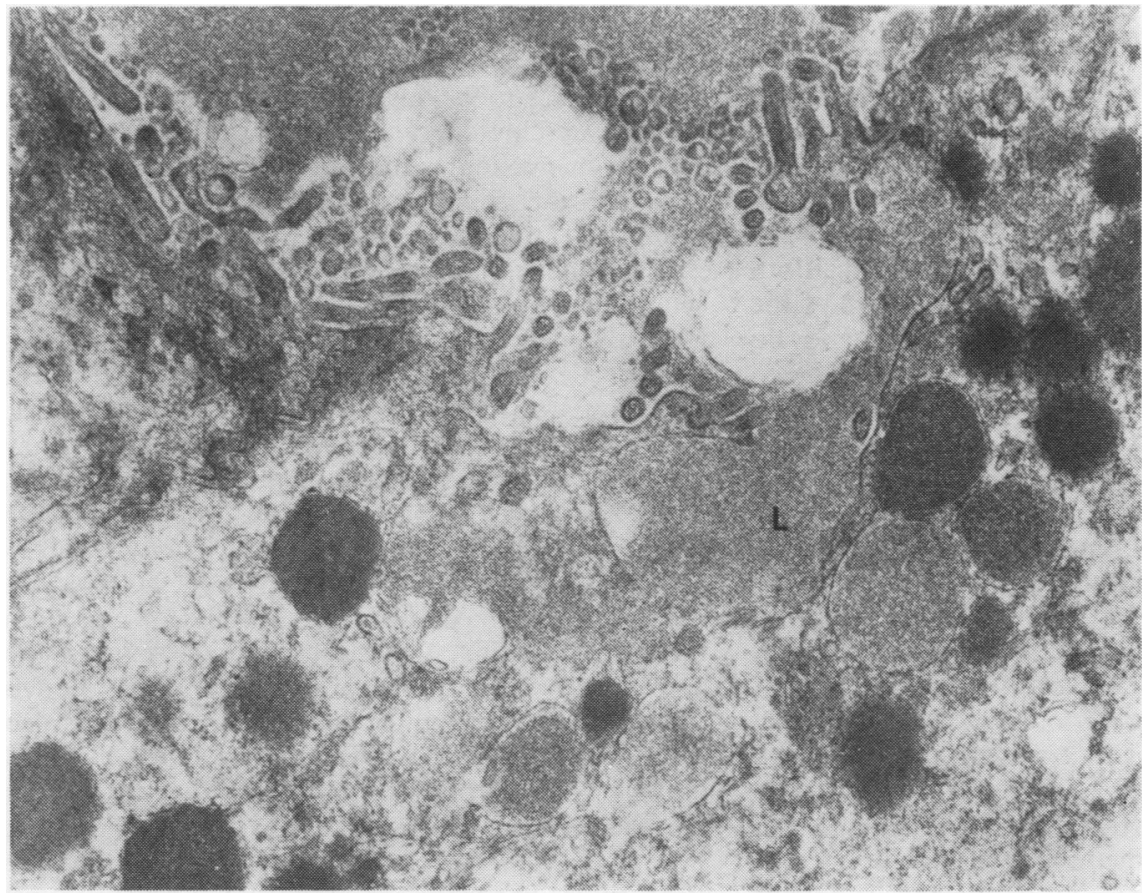

Fig 7 Case 2:

acinic cell tumour of trachea. The granules to the right appear to be contributing to the contents of the lumen (L). Electron micrograph, original magnification $\times 35000$.

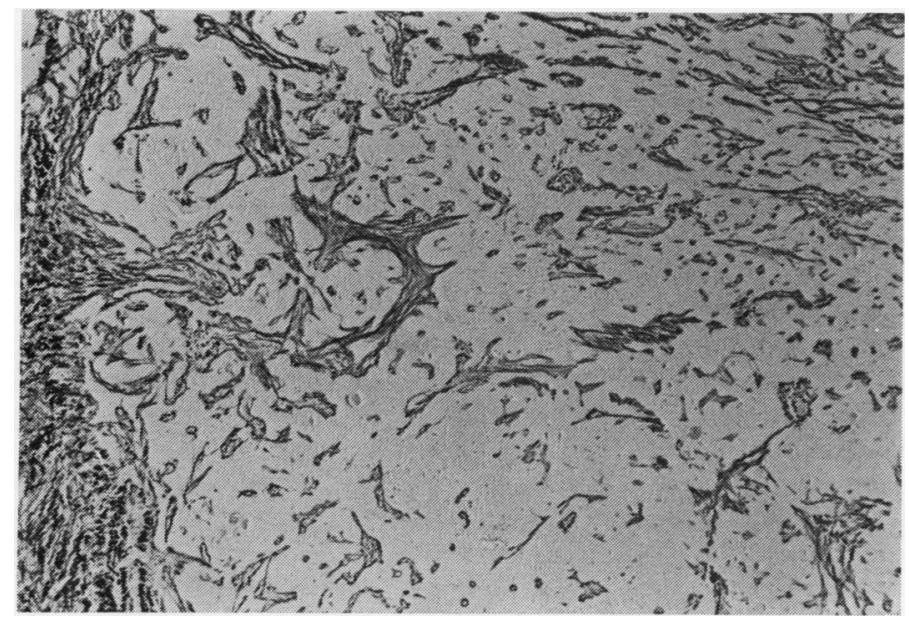

Fig 8 Case 2: acinic cell tumour of trachea stained for reticulin. The fibres are arranged between clusters of cells. Glees' stain, magnification $\times 38 \cdot 5$.

granular material (fig 6). The texture of the latter was similar to that of the granules, and a probable sequence of development could be traced from dark to pale-staining granules, and on to the pale intercellular material as a secreted product (fig 7).

The granules resembled closely those of serous cells of respiratory epithelium and bronchial glands. The absence of neurosecretory granules ruled out carcinoid tumour, and the diagnosis was changed to acinic cell tumour of the trachea.

After electron microscopy, paraffin sections were reviewed in more detail using special stains. The globules stained deeply with periodic acid-Schiff, as also did some small intracytoplasmic granules. The staining was diastase-resistant. The globules and granules did not take up Alcian blue or Sudan black stains. Reticulin fibres, stained by Glees' method, were present around bundles of tumour cells but not between individual cells (fig 8). Some intracellular granules were coloured weakly with Grimelius' method. ${ }^{3}$ 


\section{Discussion}

The present report describes how two tracheal tumours that were diagnosed as carcinoid tumours by light microscopy were found later to be a glomus tumour and an acinic cell tumour by electron microscopy. No neurosecretory granules of the carcinoid type could be found in either tumour. Both are extremely rare, only two glomus tumours of the trachea having been reported previously, and no tracheal acinic cell tumours.

The original paraffin sections on which the diagnoses of carcinoid tumours were made were shown to several senior pathologists without the information obtained by electron microscopy. They also diagnosed carcinoid tumours, and were similarly surprised to learn the ultrastructural findings. It is clear that electron microscopy will expand knowledge of tracheal and other tumours and at the same time improve diagnostic accuracy. Most tracheal tumours reported to date have not been examined by electron microscopy, so some may well have been misdiagnosed. ${ }^{4-6}$

Carcinoid tumour cells belong to the APUDsystem, ${ }^{7}$ and contain very small membrane-bound, dense core granules, 100 to $300 \mathrm{~nm}$ in diameter. ${ }^{8}$ We have examined eight carcinoid tumours of the bronchus by electron microscopy, and found these granules easily in all of them. Instead, our case 1 tracheal tumour cells contained specialised structures indicating smooth muscle or glomus cells. There was no lowpower resemblance to leiomyoma and the arrangement of polygonal cells around blood vessels was acceptable in retrospect for glomus tumour. The pericellular reticulin fibres of the glomus tumour should be useful for screening future carcinoid tumours by light microscopy.

We have found only two previous reports of glomus tumours of the trachea. The first appears to be that of Hussarek and Rieder in $1950 .^{1}$ The tumour was excised from a woman of 43 years, and diagnosed by light microscopy. The diagnosis was not checked by electron microscopy, and reticulin stains were not employed. Fabich and $\mathrm{Hafez}^{2}$ reported the second case in a man of 63 years, and our electron microscopy findings and reticulin staining results are similar to theirs.

There is one report of a glomus tumour in the lung, occurring in the left lower lobe of a woman of 67 years. ${ }^{9}$ The diagnosis was confirmed by electron microscopy. Although haemangiopericytomas also show pericellular reticulin fibres by light microscopy, electron microscopy shows no dense bodies or plaques in the cells. Glomus tumours of other sites have been studied by electron microscopy. 1011

Our second case was diagnosed as an acinic cell tumour on the basis of the granules that resembled $\overrightarrow{\vec{F}}$ those of serous cells by electron microscopy. They measured 225 to $950 \mathrm{~nm}$ (mean $440 \mathrm{~nm}$ ) in diameter, whereas carcinoid granules are seldom larger than $300 \mathrm{~nm}$ in maximum diameter. ${ }^{12}$ None of the latter were present. Similar granules have been seen in acinic cell tumours of the parotid gland, ultra- कै structurally. ${ }^{1314}$ Some authors consider that acinic $\overrightarrow{0}$ cell tumours arise from non-granular cells of the intercalated duct type, which are precursors of $\vec{\omega}$ serous cells. ${ }^{15} 16$ Incidentally, these tumours represent about one to three per cent of all parotid tumours, $\vec{x}$ and the prognosis is usually good; occasionally they metastasise, even when they are well differentiated. iv

We have not found any previous reports of acinic $\vartheta$ cell tumours of the trachea. Fechner et al, in 1972, ${ }^{17}$ 을 described one in the lung of a man of 63 years, which was $4.2 \mathrm{~cm}$ in maximum diameter and of uncertain Tा bronchial origin. By electron microscopy, the $\frac{\mathbb{D}}{5}$ granules were about $500 \mathrm{~nm}$ in diameter, and although many of them were paler than in our case, they also stained by PAS, unaltered by diastase digestion, and $\vec{\bullet}$ not by Alcian blue or mucicarmine, and were $\stackrel{\infty}{N}$ regarded as pale serous rather than mucous in type. Katz and Bubis ${ }^{18}$ later described one growing in the right main bronchus of a girl of 12 years, and thought that variations in the depth of staining of granules may be partly technical in origin.

Acinic cell tumours could arise in the trachea from at least three sources. Serous cells are well known in the acini of mucous glands, ${ }^{19}$ but they also occur in airway epithelium. ${ }^{20} \mathrm{~A}$ third possibility is from heterotopic salivary gland tissue, which has been reported in the human trachea. ${ }^{21} 22$

Electron microscopy is too time-consuming for routine use in tumour diagnosis, but it clearly has a place for special problems. Gyorkey et $a^{23}$ examined a series of tumours of the respiratory tract and other systems, and the diagnosis could be determined only by electron microscopy in three per cent. In a further five per cent, electron microscopy positively con- 은 firmed an equivocal light microscopical diagnosis. At $D$ the same time it should be noted that electron microscopy cannot always be relied upon to provide $\stackrel{\sim}{\circ}$ a diagnosis. A bronchial carcinoma, for example, may show features of more than one cell type, and in addition, factors other than the cell of origin may $\mathrm{W}$ influence differentiation patterns. ${ }^{24}$

Since our two supposed carcinoid tumours turned o out to be something else by electron microscopy, the question must be raised whether carcinoid tumours $\stackrel{?}{-}$ of the trachea exist. The presence of neurosecretory granules in all eight of our bronchial carcinoids makes it likely that light microscopy is usually reliable where the bronchus is concerned. Fourteen carcinoid tumours of the trachea are on record, ${ }^{25}$ 
but present experience throws doubt on cases that have not been checked by electron microscopy and future reports of possible cases should include this investigation. The same applies to future reports of acinic cell tumours of the trachea, which may otherwise be confused with carcinoid tumours, mucoepidermoid tumours, clear cell adenomas and metastatic renal adenocarcinomas.

We thank Mr T Buckley for help with preparations for light microscopy.

\section{References}

${ }^{1}$ Hussarek M, Rieder W. Glomustumor der Luftröhre. Krebsartz 1950;5:208-12.

${ }^{2}$ Fabich DR, Hafez G-R. Glomangioma of the trachea. Cancer 1980;45:2337-41.

${ }^{3}$ Grimelius L. The argyrophil reaction in islet cells of adult human pancreas studied with a new silver nitrate procedure. Acta Soc Med Upsalien 1968;73:271-94.

${ }^{4}$ Huguenin-Dumittan S, Kapanci Y, Rudler JC. Les tumeurs primitives de la trachée: leur aspect endoscopique, anatomique et thérapeutique. Schweiz Med Woch 1966;96:1399-408.

${ }^{5}$ Houston HE, Payne WS, Harrison EG, Olsen AM. Primary cancers of the trachea. Arch Surg 1969;99:13240.

${ }^{6}$ Grillo HC. Tracheal tumors: surgical management. Ann Thorac Surg 1978;26:112-24.

' Pearse AGE. Common cytochemical and ultrastructural characteristics of cells producing polypeptide hormones (the APUD series) and their relevance to thyroid and ultimobranchial C cells and calcitonin. Proc Roy Soc B 1968;170:71-80.

${ }^{8}$ Hattori S, Matsuda M, Tateishi R, Nishihara $\mathrm{H}$, Horai T. Oat cell carcinoma of the lung. Clinical and morphological studies in relation to its histogenesis. Cancer 1972; 30:1014-24.

9 Tang CK, Toker C, Foris NP, Trump BF. Glomangioma of the lung. Am J Surg Pathol 1978;2:103-9.
${ }^{10}$ Flöel H, Hammersen F, Staubesand J. Weitere Electronenmikroskopische Untersuchungen an den epitheloiden Gefässwandzellen; Beobachtungen an Glomustumoren (Masson). Verh Anat Ges 1967;62:295-300.

${ }^{11}$ Harris M. Ultrastructure of a glomus tumour. J Clin Pathol 1971;24:520-3.

12 Capella C, Gabrielli M, Polak JM, Buffa R, Solcia E, Bordi C. Ultrastructural and histological study of 11 bronchial carcinoids. Evidence for different types. Virchows Arch (Pathol Anat) 1979;381:313-29.

${ }^{13}$ Thackray AC, Lucas RB. Tumors of the major salivary glands. Atlas of Tumor Pathology. Fasc 10, Ser 2. Washington: Armed Forces Institute of Pathology, 1974.

${ }^{14}$ Kleinsasser O, Hübner $G$, Klein HJ. Acinuszell-tumoren der Glandula parotis. Arch Klin Exp 1967;189:33-50.

${ }^{15}$ Chen SY, Brannon RB, Miller AS, White DK, Hooker SP. Acinic cell adenocarcinoma of minor salivary glands. Cancer $1978 ; 42: 678-85$.

${ }^{16}$ Kay S, Schatzki PF. Ultrastructure of acinic cell carcinoma of the parotid salivary gland. Cancer $1972 ; 29: 235-44$.

${ }^{17}$ Fechner RE, Bentinck BR, Askew JB. Acinic cell tumor of the lung. Cancer 1972;29:501-8.

${ }^{18} \mathrm{Katz}$ DR, Bubis JJ. Acinic cell tumor of the bronchus. Cancer 1976;38:830-2.

19 Meyrick B, Reid L. Ultrastructure of cells in the human bronchial submucosal glands. J Anat 1970;107:281-99.

20 Jeffery PK, Reid L. New observations of rat airway epithelium: a quantitative and electron microscopic study. J Anat 1975;120:295-320.

${ }^{21}$ Pesavento G, Ferlito A. A benign mixed tumour of heterotopic salivary gland tissue in upper neck. Report of a case with a review of the literature on heterotopic salivary gland tissue. J Laryngol Otol 1976;90:577-94.

22 Ferlito A. Acinic cell carcinoma of minor salivary glands. Histopathology 1980;4:331-43.

${ }^{23}$ Gyorkey F, Min KW, Kristo I, Gyorkey P. The usefulness of electron microscopy in the diagnosis of human tumors. Hum Pathol 1975;6:421-40.

${ }^{24}$ McDowell EM. McLaughlin JS, Merenyi DK, Kieffer RF, Harris CC, Trump BF. The respiratory epithelium. V. Histogenesis of lung carcinomas in the human. $J$ Natl Cancer Inst 1978;61:587-605.

${ }^{25}$ Briselli M, Mark GJ, Grillo HC. Tracheal carcinoids. Cancer 1978;42:2870-9. 